\title{
Edgar Allan Poe and neurology
}

\author{
Edgar Allan Poe e a neurologia \\ Hélio Afonso Ghizoni Teive ${ }^{1}$, Luciano de Paola², Renato Puppi Munhoz ${ }^{3}$
}

\begin{abstract}
Edgar Allan Poe was one of the most celebrated writers of all time. He published several masterpieces, some of which include references to neurological diseases. Poe suffered from recurrent depression, suggesting a bipolar disorder, as well as alcohol and drug abuse, which in fact led to his death from complications related to alcoholism. Various hypotheses were put forward, including Wernicke's encephalopathy.
\end{abstract}

Keywords: neurology, literature, alcohol abuse, depression, Wernicke’s encephalopathy.

RESUMO

Edgar Allan Poe foi um dos mais celebrados escritores do mundo. Ele publicou várias obras primas, algumas delas com referências a diversas doenças neurológicas. $\mathrm{O}$ autor apresentou quadro depressivo recorrente, sugestivo de distúrbio bipolar, com abuso de álcool e de drogas, e morreu devido a complicações do alcoolismo, com diferentes hipóteses, incluindo a encefalopatia de Wernicke.

Palavras-chave: neurologia, literatura, alcoolismo, depressão, encefalopatia de Wernicke.

Edgar Allan Poe (1809-1849) is considered one of the greatest writers of universal literature and was the author of various masterpieces, including the famous poem "The Raven", published in $1845^{1,2}$. He has been claimed as the forerunner of the detective novel, and is known particularly for his horror stories and tales of mystery ${ }^{1,2,3,4}$. Poe's life was marked by countless adversities, including family dilemmas, poverty, disease (tuberculosis), traumatic deaths in the family, alcohol and drug abuse, and mood and behavioral disorders ${ }^{1,3,4}$. The aim of this article is to review the relationship between neurology and the author, particularly the cause of his premature death.

\section{THE PROTAGONIST}

Edgar Allan Poe (Figure) was born in the city of Boston, United States of America, on January $19^{\text {th }}, 1809$, son of to two touring actors, David Poe and Elizabeth Arnold. He became an orphan as a child and was adopted by John Allan and Frances Kelling from Richmond, in the American state of Virginia ${ }^{1,3,4}$. Later, the family lived in different American and British places. He started his studies at University of
Virginia in Charlottesville in February 1826. Poe was never disciplined for any misconduct at the University, but he did engage in gambling and ran up a debt of about 2000 American dollars, that added to the money he needed for his tuition and living, forced him to leave the school. The whole situation was probably the cause of a traumatic he had with his foster father upon his return home. At age 18, Poe moved to Boston and quickly arranged the publication of his first book, a collection of poems under the title Tamerlane. Despite his authorship, Poe didn't put his name anywhere in it and instead simply gave author's credit to "A Bostonian," perhaps hoping that the book would get more attention since Boston was then a literary mecca. This didn't work and Poe's money and effort went lost. At this point, Poe had no money and had no skills for any specific job, other than a writer. His next move was to enlist in the army on May, 1827. He was discharged after two years, and decided to go for the next step his military life, attending West Point Military Academy in the state of New York in July 1930. Less than one year later, on February 1831, he was expelled after been judged for neglect of duty and disobedience of orders to attend formations, classes, or church ${ }^{1,3,4}$. His many family problems included being abandoned by

\footnotetext{
${ }^{1}$ Setor de Distúrbios do Movimento, Serviço de Neurologia, Departamento de Medicina Interna, Hospital de Clínicas, Universidade Federal do Paraná, Curitiba PR, Brazil;

${ }^{2}$ Setor de Epilepsia e Eletroencefalografia, Serviço de Neurologia, Hospital de Clínicas, Universidade Federal do Paraná, Curitiba PR, Brazil;

${ }^{3}$ Movement Disorders Centre, Toronto Western Hospital, Toronto University, Toronto, ON, Canada.

Correspondence: Dr. Hélio Teive; Rua General Carneiro, 1103/102; 80060-150 Centro, Curitiba PR, Brasil; E-mail: hagteive@mps.com.br

Conflict of interest: There is no conflict of interest to declare.

Received 08 February 2014; Accepted 27 February 2014.
} 
his father during his early childhood as a result of problems related to alcoholism, the deaths of both his mother and foster mother due to tuberculosis and disagreements with his foster father. He also had financial difficulties and endless problems when working as a journalist and writer because of frequent bouts of depression, mood swings and abuse of substances such as alcohol, opium, laudanum and morphine ${ }^{1,3,4}$. He became involved with different women and eventually married his 13 year-old cousin Virginia Clemm, who also died from tuberculosis eleven years after their union. Among the more notable works in the various books published by Poe are, in addition to the famous poem The Raven, Tamerlane and Other Poems, The Adventures of Arthur Gordon Pym, Tales of the Grotesque and Arabesque, and Extraordinary Tales, which includes the short stories The Fall of the House of Usher, The Black Cat, The Cask of Amontillado and The Murders in the Rue Morgue ${ }^{1,2,3,4,5}$. Poe died in Baltimore, USA, on October 7, 1849, at the early age of $40^{1,2,3,4,5}$.

\section{NEUROLOGICAL DISEASES IN POE'S WORKS}

Various works by Poe contain references to epileptic seizures, an example being the short story The Pit and the Pendulum $^{4}$. In other stories, such as Berenice and The Sphinx, there are also references to episodes that resemble complex partial epileptic seizures ${ }^{4}$. In the famous story The Fall of the House of Usher, Roderick Usher and other members of his family suffer from a hereditary disease that presents as pallor (anemia), hypersensitivity to light and weakness of the extremities together with behavioral disorders. This very detailed description led authors to the conclusion that Poe was describing porphyria, which had yet to be described in the literature ${ }^{4,6}$. In another story (The Business Man), Poe describes the main character, "the business man", in great detail. The character had suffered a head

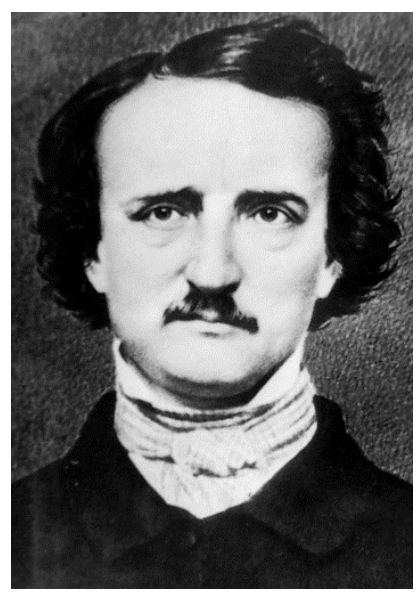

Figure. Edgar Allan Poe (1809-1849). trauma during childhood and subsequently developed a frontal dysexecutive syndrome with obsessive-compulsive components, reduced affection and antisocial behavior due to a probable lesion of the prefrontal cortex, a clinical picture similar to that of the almost iconic patient Phineas Gage? Finally, in A Tale of the Ragged Mountains, Poe gives a detailed description of a character with characteristics consistent with Marfan syndrome. A description of this syndrome was published by Antoine Marfan in Paris, France, in $1896^{8}$.

\section{NEUROLOGICAL DISEASES AND POE'S DEATH}

Edgar Allan Poe's medical history and death are the source of much speculation, and different hypotheses have been suggested in the medical literature ${ }^{1,3,4,5}$. Poe's behavior, with recurring episodes of depression and behavioral changes, together with abuse of alcohol and other drugs, such as opium, laudanum and morphine, could suggest a diagnosis of bipolar affective disorder with periods of depression and hypomania ${ }^{1,2,3,4,5}$.Undoubtedly, the episodes of depression could also have been triggered by countless environmental factors related to his family, including disease, death and financial hardship. Reports that Poe was extremely sensitive to alcohol, with exacerbated behavioral changes, resulted in a diagnosis of pathological intoxication being suggested ${ }^{4}$. The hallucinatory symptoms observed could also have been associated with the use of drugs and occasional abstinence from alcohol ${ }^{4,5}$. Bazil, in an article published in 1999, put forward the hypothesis that Poe may have suffered from temporal lobe epilepsy triggered by alcohol abuse, which would explain the periods of confusion, with psychomotor automatisms and visual hallucinations (ictal and postictal states) ${ }^{9}$. Another enigma in Poe's life is the actual cause of his death at Washington College Hospital in Baltimore, USA. He was found in a state of acute confusion in a tavern and was attended to by Dr. Moran ${ }^{1,3,4,5,9}$. The information about Poe's last days is somewhat vague, and it is not clear whether he was indulging in alcohol abuse or abstaining from alcohol and possibly experiencing the onset of delirium tremens ${ }^{1,3,4,5,9}$. What is known is that he was found in a highly confused state suffering from visual hallucinations and allegedly repeating the words "Reynolds! Oh! Reynolds!" endlessly and finally "Lord, help my poor soul." Poe became comatose and was described as having dilated pupils. He died within three days, and a diagnosis of "congestion of the brain" due to hepatic encephalopathy caused by alcoholism was made ${ }^{1,3,4,5,9}$. Other hypotheses put forward included lung infection and sepsis, a previous head trauma during alcoholic intoxication with the development of an extradural hematoma, nonconvulsive status epilepticus and syphilis ${ }^{1,3,4,5,9,10}$. One last possible diagnosis is Wernicke's encephalopathy, or Wernicke-Korsakoff 
syndrome. Wernicke's encephalopathy, which is associated with, amongst other causes, alcohol abuse with thiamine deficiency, is defined by the triad of signs consisting of gait ataxia, mental confusion and abnormal eye movement. However, in daily clinical practice the patient may very often become comatose without having presented with the original triad.
In conclusion, Edgar Allan Poe, the gifted American writer, published various masterpieces with references to a range of neurological disorders. He presented with a clinical picture of depression suggestive of a bipolar disorder and suffered from alcohol and drug abuse. He died in mysterious circumstances with suspected complications related to alcoholism and Wernicke's encephalopathy.

\section{References}

1. Ackroyd P. Poe.: A life cut short. Edhasa, Barcelona, Espanha, 2009.

2. Harris JC. Edgar Allan Poe: The Raven. Arch Gen Psychiatry 2008;65:868-869.

3. Patterson R. Once upon a midnight dreary: The life and addictions of Edgar Allan Poe. Can Med Assoc J 1992;147:1246-1248.

4. Miranda MC. La historia médica de Edgar Allan Poe. Rev Med Chile 2007;135:1216-1220.

5. Courtney JF. Addiction and Edgar Allan Poe. Med Times 1972; 100: 162-163.
6. Rickman LS, Kim CR. "Poe-phyria", madness, and "The fall of the house of Usher”. JAMA 1989;261:863-864.

7. Altschuler EL. Prescient description of frontal lobe syndrome in an Edgar Allan Poe tale. Lancet 2004;363:902.

8. Battle RW. Edgar Allan Poe: a case description of the Marfan syndrome in an obscure short story. Am J Cardiol 2011;108:148-149.

9. Bazil CW. Seizures in the life and works of Edgar Allan Poe. Arch Neurol 1999;56:740-743.

10. Gordon AG. The death of Edgar Allan Poe - a case of syphilis? Md Med J 1997;46:289-290. 